\title{
Tourism as an interpretive and mediating influence: A review of the authority of guidebooks in protected areas
}

\author{
By \\ Stephen L. Wearing and Amy E. Whenman \\ University of Technology, Sydney \\ $\underline{\text { Contact Details }}$ \\ Stephen Wearing \\ Associate Professor \\ School of Leisure, Sport and Tourism \\ University of Technology, Sydney \\ PO Box 222 Lindfield NSW 2070 \\ Australia \\ Tel: +61295145432 \\ Email: stephen.wearing@uts.edu.au
}




\title{
Tourism as an interpretive and mediating influence: A review of the authority of guidebooks in protected areas
}

\begin{abstract}
This review sees to present the outcomes of a study which examined the potential effectiveness of guidebooks as a form of interpretation in reducing environmental impacts in a national park. It provides a review based on information gained from interviews with twenty nine trekkers undertaking the Overland Track in Tasmania, Australia. Results from the interviews where correlated with the literature and indicate that trekkers are more likely to use guidebooks at the planning stage of a trek in order to make decisions about what area to visit, what equipment to take, transport and accommodation. The guidebooks used by trekkers in this inquiry were found to have only a small amount of information on minimal impact messages and such messages were found to be poorly structured. As a result guidebooks were found to have little influence in mediating responsible environmental behaviour in protected areas. The study recommends that well structured minimal impact messages be incorporated into guidebooks using the Elaboration Likelihood Model of attitude change and persuasion to direct the process.
\end{abstract}

Keywords: guidebooks, tourists, protected areas, minimal impact messages, attitudes, persuasion, behaviour change. 


\section{Introduction}

With increasing access and use of protected areas by tourists, guidebooks offer the potential to become a popular and distinct form of interpretation. At present a combination of public and private sector organisations provide information for visitors to protected areas (Wearing, Archer \& Beeton, 2007). However, much of the content that appears in text (either electronically or in publication) is not necessarily endorsed by protected area agencies raising questions concerning the appropriateness of this material for enhancing the experience of the tourist and mitigating environmental impacts.

Environmental interpretation is achieved through the provision of educational information about a specific area either through a tour guide and/or printed/electronic material (Ham \& Weiler, 2002). Guidebooks are a type of interpretation defined as texts which are "dynamic agents that are continually influencing, modifying and reifying the meanings, beliefs and ways of seeing contemporary cultural groups and environments” (McGreggor, 2000, p. 28).

In the last 20 years tourists have become significant users of protected areas and frequently make use of books, brochures, DVD's and websites to gain information and understanding on the areas they intend to visit (Eagles \& McCool, 2004). Given the popularity of guidebooks as a source of information this paper seeks to review the way in which tourists use these when visiting protected areas and their potential influence on responsible environmental behaviour. Despite the growth in visitors to protected areas little attention has been paid to the role guidebooks play in reducing environmental impacts. 


\section{Guidebooks and Tourism}

Tourists refer to a variety of travel related literature before, during and after their travels including travel narratives, ethnographic accounts, glossy souvenir picture books, tourist brochures and guidebooks (Therkelsen \& Sorensen, 2005). Guidebooks make up a significant portion of the travel related literature. For example, Lonely Planet, one of the world's largest and most popular publishers of travel guidebooks, made over US\$80 million in sales in 2001. As the number of guidebooks being produced and purchased increase they have become, "the mediating link between the tourist and the tourism destination” (Therkelsen \& Sorensen, 2005, p. 49). For many tourists the guidebook has replaced the tour guide or travel broker as the mediating agent between the tourist and the tourist site as brands such as Lonely Planet, Rough Guide, and Footprint have become ubiquitous. Therkelsen and Sorensen (2005) identify four features that differentiate guidebooks from other types of travel literature:

1. Non-local as the target market: the reader knows little about the geographical area represented.

2. Knowledge and emotional experiences can be gained from reading: both cognitive and affective processes are involved.

3. Geographical area/special interest is represented: continent, country, region, city, or special interest such as trekking or cycling.

4. Evaluation of a geographical area is presented: attractions and sites are evaluated and a rating system such as stars is often used.

In order to take advantage of the growing popularity of electronic sources used by travellers many guidebook publishers have developed companion websites that contain further up to 
date travel information, and online forums where travellers can communicate with each other and post questions and queries (e.g. Lonely Planet, 2008).

To date, research on guidebooks in the tourism literature has tended to focus on content, in particular the representation of place (e.g. Beck, 2006; Bhattacharyya, 1997; Jacobsen, Heimtun \& Nordbake, 1998; Kelly, 1998; Lew, 1991; Scott, 1998; Siegenthaler, 2002; Vaughan, 1974). Many of these studies assume that guidebooks “determine tourists' behaviour and understanding of places” (Therkelsen \& Sorensen 2005, p. 49). As Lew (1991) notes, guidebooks not only help shape expectations but "also the destination behaviour of tourists as they seek to create a restorative experience” (p. 126). However, McGreggor (2000) argues that this assumption is incorrect and that tourist behaviour is also influenced by word of mouth and the tourist's previous experiences.

Therkelsen and Sorensen (2005) found that tourists use guidebooks in a number different ways. They developed a typology of uses that included the information addict and planner, both of whom relied heavily on their guidebooks to provide cultural/historical information and ready to use answers, whereas the functional minimalist uses a guidebook more sporadically, and only as a source of ready to use answers. Nishimura, Waryszak and King (2006) conducted a qualitative study on the use of guidebooks by Japanese tourists travelling in Australia finding that independent travelers are far more likely to use guidebooks then those on a guided package tour. In a follow up study the authors (Nishimura, Waryszak \& King, 2007) used a quantitative design to understand how guidebooks are used by Japanese overseas tourists. They identified five different use classifications including functional needs (obtain information), forward looking needs (choosing a destination and planning a vacation), enjoyment needs (anticipating a destination), learning needs (developing cultural and 
environmental understanding) and guidebook enthusiast needs (post-reflection).

\section{Protected Areas and Environmental Impacts}

The number of people visiting protected areas around the world is on the rise (Eagles \& McCool, 2004, p. 37-39). As numbers of visitors increase so to do the negative environmental impacts (Buckley 2004), posing a growing problem for protected area managers in their efforts to conserve these areas. The growth in the number of protected areas around the world has also risen as Figure 1 indicates (Eagles, McCool \& Haynes, 2002). In 2002, 44,000 sites were registered as protected areas around the world, covering $10 \%$ of the land surface of the planet (Eagles et al., 2002). Many of the world's major tourist attractions are now found in protected areas, putting unprecedented pressure upon them. This is the result of a growing concern and interest in the environment, increased levels of education, cheaper international air travel, and an ageing population in the world's advanced industrialised countries (Eagles et al., 2002).

\section{[Insert Figure 1]}

There are a variety of impacts that result from visitation to protected areas and these impacts occur on different scales, from a solitary hiker, to intensive accommodation and development within the boundaries of a national park. Buckley (2004) notes:

the type and degree of impacts depend on a range of factors, including: number of people, group size, activity, equipment, minimal impact skills and practices, ecosystems, season and management regime. (p. 11-12) 
Environmental impacts can be viewed in a number of ways. The law may deem an impact unacceptable and enforced by an authority like a national park service, or by society’s perceptions and influence. Roggenbuck (1992) describes five types of undesirable behaviour: “careless, unskilled, uninformed, unavoidable, and illegal” (p. 163).

[Insert Table 1]

Research has found that persuasive communication can effectively influence unskilled and uninformed behaviour and to a certain extent careless behaviour (Marion \& Reid, 2007). However, not all behaviour can be influenced and this needs to be taken into account when designing strategies to reduce visitor impacts in protected areas.

\section{Guidebooks and Interpretation}

Guidebooks come in various types and typically focus on a single country, group of countries in close proximity, cities, regions, phrase books and cultures, as well as guides for specific activities such as cycling, trekking, and diving. Some guidebooks are designed to inform tourists on what sites to visit, transport and accommodation in a particular country, region or city, while others seek to inform the traveller about culture, customs, natural features/landscapes, and behavioural expectations. There are a number of features that combine to produce an effective guidebook including the provision of accurate information, knowledge and education about cultural differences, environmental features and language.

Guidebooks are an important reference tool for all types of tourists. Destinations that were once remote, unknown or difficult to negotiate have now been opened up allowing independent travellers to venture into these areas. Guidebooks can also be viewed as a form 
of interpretation, enhancing a visitors understanding and appreciation of the environment and cultural phenomena experienced (Ham \& Weiler, 2002, p. 36).

The three key goals of interpretation are "knowledge gain and awareness increase, attitude change and behaviour modification” (Tubb, 2003, p. 479). Studies have found that interpretation is a key strategy to achieving sustainable tourism development (Ballantyne \& Packer, 2005; Ham \& Weiler, 2002; Hill, Woodland \& Gough, 2007; Hughes \& Saunders, 2005; Littlefair, 2004; Tubb, 2003). The effectiveness of interpretation in protected areas is measured by the degree to which information has been conveyed to the visitor, attitudes are influenced and behaviour is changed (Kuo, 2002). If visitors have an understanding of key conservation issues than attitudes and behaviour are more likely to be affected (Ajzen, 2005; Iozzi, 1989; Tubb, 2003). Phillips (1989) states that in order for interpretation to modify behaviour visitors need to understand the connection between a site, their potential impacts, and consequent actions that can be taken to reduce these impacts.

An important facet of interpretation is education. Like interpretation, education is used to manage protected areas. Educational programmes are often adopted to minimise impacts and include programmes such as Leave No Trace, Codes of Conduct and Environmental Guidelines for Tourists (Marion \& Reid, 2007). If education programmes are to be successful in reducing environmental impacts in protected areas then messages need to be persuasive. Persuasion Weaver (2006) argues is a more sophisticated form of intervention then regulation, which relies on unsightly physical barriers, signage and expensive policing strategies. Tubb (2003) notes, “visitors have to be motivated and encouraged to engage in learning” and information cannot just be presented to visitors; “visitors need to be stimulated to search for new information and encouraged to actively process information” (p. 480). 
Therefore, the types of instructions that are given in codes of conduct need to provide explanations as well so that visitors can understand and reflect on their thinking and behaviour. Communication in the form of interpretation and education needs to go beyond presenting cold hard facts if it is to be effective (Kuo, 2002; Roggenbuck, 1992). Kuo notes:

Visitors are unlikely to be touched by bare factual information. However, if the worries, beliefs, sense of humour, concerns etc. common to humankind can be interwoven into the interpretation, it will attract visitor attention more easily, and the information may be memorised for longer. $(2002,97)$

Results from research indicate that in order for interpretation to be effective it needs to provide knowledge, and the impetus to change attitudes and behaviour (e.g. Hill, Woodland \& Gough, 2007; Hines, Hungerford \& Tomera, 1986/87; Hughes \& Saunders, 2005; Hungerford \& Volk, 1990; Orams, 1997). Previous research in the area has tended to focus on evaluations of interpretive materials and mediums (displays, signage, brochures, films, tour guides etc.) as opposed to measuring the attitudinal and behavioural outcome of interpretation programmes (Ballantyne \& Packer, 2005; Munro, Morrison-Saundersa \& Hughesb, 2008).

\section{Interpretation and Behaviour}

A key objective of interpretation in protected areas is to modify behaviour in order to reduce environmental impacts. Social psychologists such as Ajzen (2005) argue that people generally act consistently with their attitudes. Therefore, effective interpretation is a process of providing information, increasing knowledge, changing attitudes, leading to responsible environmental behaviour (Tubb, 2003, p. 479). Early models illustrating the interpretation process, such as Hungerford and Volk’s (1990) Linear Behavioural Change System provide a basic understanding of how this process works (see Figure 2). This model is based on the 
assumption that as knowledge of the environment increases environmental attitudes are shaped, leading to corresponding environmental behaviour.

\section{[Insert Figure 2]}

More recent research on responsible environmental behaviour suggests the relationship between knowledge, attitudes and behaviour change is more complex then that proposed by Hungerford and Volk. For example researchers such as Bright (1994), Cottrell and Graefe (1997), Ham and Weiler, (2002), Iozzi (1989) and Orams (1996, 1997) are more cautious about assuming that increased knowledge leads to behaviour. They draw more realistic conclusions by arguing that a particular attitude doesn't always lead to a corresponding behaviour.

Prominent theories of behaviour change (general and environmental) include the Theory of Planned Behaviour, the Elaboration Likelihood Model, and the Model of Responsible Environmental Behaviour. All three models theorise a link between knowledge, attitudes and behaviour.

[Insert Table 2]

\section{Methodology}

In setting out the parameters of this exploratory inquiry an overriding research question was developed: Are guidebooks an effective interpretation tool for reducing environmental impacts in protected areas? In order to begin answering this question twenty nine trekkers 
were recruited while walking the Overland Track in the Cradle Mountain-Lake St Claire National Park, in the Australian state of Tasmania (see Figures 3). A convenience sample of walkers stopping or staying at the Windy Ridge Hut from 31 March to 3 April 2007 was taken. The interviews were semi-structured in nature and focused on the topic of guidebook usage. Questions included the type of guidebooks used, what minimal environmental impact information they contained, and what decisions and behaviours the guidebook(s) might have influenced. Each of the interviews was recorded with the permission of the participant and transcribed verbatim at a later date.

[Insert Figure 3]

Analysis of the data was guided by Minichiello, Aroni, Timewell and Alexander (1995). In the first phase the interview transcripts were inputted into the qualitative software programme NVivo version 6 . The key advantage to using computer assisted qualitative data analysis is that it takes over the manual labour involved in coding, as well as making the coding process more efficient (Bryman, 2001). In effect NVivo performed the descriptive functions which complemented the interpretive phase of the analysis (Minichiello et al. 1995, p. 270).

Coding of the interviews was conducted in the field and then later when the data was being analysed. The coding process involved identifying themes that were significant in the participant's responses. Coded data was counted in numerical terms and also examined for meaning. Based on Minichiello et al. (1995) codes were developed by analysing words (a frequency count of words that are deemed significant or an examination of the ways that words appear in text), concepts (words grouped together in clusters to indicate particular ideas) and sentences (the location of words, concepts and themes in sentences). Six core 
themes eventually emerged from the data. These are outlined below and expanded upon in more detail in the following section.

1. Guidebooks were used predominately at the planning stage (off site) of a trek along with other sources of information.

2. Guidebooks were found to be difficult to use at the trekking stage (on site).

3. Guidebooks influenced general behaviours related to trekking as opposed to specific minimal impact behaviours.

4. A variety of guidebooks were used by the participant's, each containing particular features.

5. The most influential source of minimal impact information was found on the track itself.

6. Minimal impact behaviour was also found to be influenced by previous experience.

\section{Trekkers Experiences of Using Guidebooks on the Overland Track}

Results from the interviews found that $60 \%$ of the participants had used a guidebook as a part of visiting the Overland Track. In all six guidebooks were used, these included The Overland Track: One walk many journeys (TPWS, 2006), The Overland Track (Chapman \& Chapman, 2006), Cradle Mountain-Lake St Clair and Walls of Jerusalem National Parks (Chapman, Chapman \& Siseman, 2006), the Lonely Planet Guide to Tasmania (Bain, Tsarouhas \& Brown, 2005), the Lonely Planet Guide to Walking in Australia (Bain, Brown, Connellan, Daly, Dixon \& van deer Knife, 2006), and the Lonely Planet Guide to Australia (Vaisutis, Murphy, Dunford, Carter, Dunston, Gaskell et al., 2007). Six participants used more then one guidebook, in these cases this included a combination of the Tasmanian Parks and Wildlife Service (TPWS) guidebook (The Overland Track: One walk many journeys) with another 
guidebook. The Overland Track: One walk many journeys (TPWS, 2006) was the most popular guidebook as it was included in an information pack that walkers had the option of purchasing when booking to walk the track (bookings are required between 1 November and 30 April).

The majority of walkers consulted guidebooks at the planning stage indicating that this is when they are likely to be most influential.

\footnotetext{
The booklet was interesting to read prior to the trip, but hard to access during the trip because of rain. (John)
}

No I haven't used a guidebook, but the original idea of doing this trek came from reading the Lonely Planet Tasmania. (John)

We looked at the Lonely Planet Tasmania to get some background information, particularly for information on accommodation. (Amanda)

Some problems using guidebooks on the walk were identified.

The info in the booklet on plants etc was good but we didn’t bring it out cause of the weather and difficulty of the walk. (John)

The Park's booklet was good to read prior to the walk but we didn't bring it with us. We thought it would be unnecessary extra weight. (Alison)

The booklet (TPWS booklet) needs to be waterproofed and so does the map. (Jane) 
Participants identified a number of factors related to guidebooks that increased their awareness and influenced their behaviour in some way. These included:

1. Decision to walk the Overland Track.

2. The trekking route. Decisions here were made with the aid of maps, trekking distances, location of huts, side track options.

3. Transport.

4. Accommodation.

5. Natural environment.

Table 3 below contains the two most citied features of each guidebook read by the trekkers on the Overland Track.

[Insert Table 3]

The Overland Track (Chapman \& Chapman, 2006) received high praise from those walkers who used it because it provided the most detailed information with regards to maps, distances, timings, sidewalks, location of huts and camping grounds. The following quotes illustrate:

The topo (topographic) maps, what to bring, relief maps, information on huts and the trek plan (were all great features). (Anna)

The Chapman book was very useful. Descriptions on the terrain, hut locations, distances and journey plan were all very useful elements. These features made it easier to define our limits. (Cathy) 
The Lonely Planet guides to Tasmania, Australia and Walking in Australia were noted for their general information such as accommodation, transport and information on protected areas in Tasmania.

\footnotetext{
We looked at the Lonely Planet Tasmania to get some background information, particularly for information on accommodation. (Amanda)
}

In the Lonely Planet we found the information about the trip description to be useful. (Madeline)

The potential of guidebooks to influence behaviour depended on what guidebook was used, and whether it was used during the trek. Those trekkers that used their guidebooks while on the track consulted track notes and maps, which were found to be influential in terms of decisions been made about what tracks to take, features to view, hut usage and camping.

The cross section map was great so we could see what to expect for the day. The pictures of flora and fauna were good, as well as the information on the history and context. (Tim)

In Chapman I found the distances, times and information on sidetracks to be useful. In the Park's booklet I thought that the history and background information was interesting but I thought I didn't really need to bring this book with me. It is pretty general. (David)

The participant's also identified information sources other then guidebooks that were used in the planning stage of the walk. These are noted in order of importance:

a. Tasmania Parks and Wildlife Service (TPWS) website. 


\section{b. Topographic maps. \\ c. Friends and relatives. \\ d. Past walking experience.}

e. On track information sources: Information in toilets, huts and signage.

\section{f. Other websites.}

The official website (Parks website) had good information on weather, clothes, animals/wildlife, safety and rubbish (disposal). (Madeline)

I didn't use guidebooks that much (for information on trek plan); just the Lonely Planet to get general information, but the Internet was most useful. (Tim)

The features (of the map) I found useful have been the distances, times, side trip information, and the profile was very handy. (James)

Also we chatted with some friends that had walked the track and got some great information from them. (Amanda)

Yes (my friend was the main influence when deciding to do the track). I didn't know about the track until a friend told me. (Matt)

During the trekking stage the most commonly cited and influential source of minimal impact messages (MIMs) were posters and signs found in the huts, toilets and along the track itself.

All the toilets along the way have had a big laminated poster inside telling you to stay on the track, don't light open fires and that sort of stuff. You can't help but take notice to that, it's in every toilet. (Harry) 
The participant's utilised guidebooks to gain information on a number of aspects of the natural environment and they each contained a modest level of detail on MIMs. Table 4 provides a comparison between each.

[Insert Table 4]

Information about the areas natural features such as landscapes, geology, flora and fauna was obtained mainly from guidebooks at the planning stage and in the huts along the walking route. This information was found to enhance the walking experience. Only 6 of the 29 participants interviewed identified guidebooks as influencing their knowledge of environmental impacts in some way. Environmental impact awareness was more likely to be influenced by past experiences, the Internet and park service information provided on the track. The majority of the trekkers stated that responsible environmental behaviour is developed over time and through experience. The two main on track information sources were materials and posters found in huts and toilets. Other sources included the Overland Track website, signage along the route and park service rangers.

I read some information on impacts in Chapman, but my past trekking has developed my knowledge of impacts and how to act when trekking. (Cathy)

A small amount of info in the info pack and a little on the website. (Jane)

We kind of know...it's mainly just common courtesy. Like a lot of the stuff has really been drilled into us...we've sort of just picked it up and learnt it very well over the past few years. Keep on the track and don't light fires and all that sort of stuff. (Harry) 
The participants identified a variety of ways that environmental impacts can be minimised when trekking in protected areas. The majority of participant's were able to list between 2-3 impacts. Below is a list of responses:

- Stay on the track.

- Picking up rubbish.

- Correct toilet behaviour.

- Not using soaps/detergents.

- Not feeding animals.

- Not lighting fires.

- Camping in designated campsites.

- Not washing in rivers.

One of the major environmental impacts on the Overland Track is erosion and trampling of flora caused by walkers straying off the designated track. Due to the high levels of rainfall in the area many parts of the track become flooded and muddy so that new tracks appear in order to avoid these areas. This is a significant problem for the park service to manage as the following quotes illustrate.

I took the occasional short cut for safety and practicality. I wanted my boots to stay dry and maintain comfort. I was conscious of maintaining the track as well. (Paul) 
Only where people have already walked, some places there's tracks along the sides, based on safety, I've gone around the side, only where people have already done it and it's a quite defined track. (Natalie)

In some flooded sections we walked around the sides. (Amanda)

we took short cuts...especially the other day when it was raining so badly, like what day was it...Friday, it just poured the whole day and so there was bits of track that you just couldn’t walk in. The track would be going around here (pointing) and there would be another bit that come up that other people had already made into a track, so that....If you are on the walk and you have to go off the track for a minute, I just keep walking until I see an animal track and then pull in there, you don’t just trample plants, we rock hop. (Harry)

\section{Discussion}

Overall guidebooks were found to be an important source of information at the planning stage of a trek where they were used to make decisions about what area to visit, accommodation, transport and equipment. Other sources of information used at the planning stage by the participant's in this inquiry include the TPWS website, topographic maps, friends and relatives, and past walking experience. During the trekking stage the most commonly used sources of information were those provided by the TPWS found in huts,

toilets, and on the track itself, as well as topographical maps. The content of guidebooks and their influence on responsible environmental behaviour was found to be minimal as these were often left behind in order to reduce weight, or they were difficult to use in wet and windy weather conditions which are frequently encountered on the track.

Guidebooks were found to be an important element within the overall trekking information mix (see Figure 4). Each of these information sources contains a number of unique attributes 
that make them useful for trekkers at both the planning and trekking stage. Each source has the potential to influence knowledge, attitudes and behaviour. For example, the internet may be accessed for information on hut locations and distances, whereas friends and relatives may provide information on recommended sidetracks, distances and timing. The results from this study support previous research that trekkers use a variety of information sources at the planning and trekking stage (Wearing, Archer \& Beeton, 2007) and that interpretation comes from a variety of sources and contexts. Guidebooks were found to be one of the sources of information on protected areas and therefore a potential source of MIMs.

[Insert Figure 4]

A review of the guidebooks used by the trekkers in this inquiry found that MIMs were poorly structured, inconsistent, provided little explanation, and were rarely persuasive. A previous study conducted by one of the authors on the Kokoda Track in Papua New Guinea found that MIMs are effective when they are consistent and well structured. A study of minimal impact education conducted in the Australian Alps National Parks revealed the need to rework existing MIMs in order to "increase visitor awareness and compliance through more effective communication” (Beckmann 2003, p. 130). Table 5 and Figure 5 illustrate and explain the hierarchical structure used by Beckmann (2003) to design MIMs.

[Insert Table 5]

[Insert Figure 5] 
A study on safety and MIMs conducted by Stewart, Cole, Manning, Valliere, Taylor and Lee (2000) in the Grand Canyon National Park, Arizona found that messages need to be consistent if they are to promote environmentally responsible behaviour. The authors found the most influential sources of information and interpretation for visitors were the official parks guide (presented in a newspaper style format) distributed to visitors upon entry, posters displayed throughout the Park and signage. This result was replicated in this inquiry, as well as supporting research in the area of social and consumer psychology, which indicates that changes in attitudes are more likely to form when there is repeated exposure to the message (Bright, 1994).

While guidebooks have the potential to function at all stages of a trek (see Figure 6) the results of this inquiry indicate that their influence is greatest at the planning stage when visitors are carrying out research on possible destinations. Wearing, Cynn, Ponting and McDonald (2002) in a study of backpackers 'green’ purchasing habits found that responsible environmental behaviours are more easily influenced in the home environment then at the destination site. At present the emphasis on responsible environmental behaviour by protected area managers is onsite (where they obviously have most control) in the form of signage, leaflets and visitor centres.

[Insert Figure 6]

Knowledge of appropriate minimal impact behaviour is not only important for modifying behaviour on site in a protected area, but also ensuring that a visitors future visit will be conducted with the requisite knowledge and skills to reduce environmental impacts. So far this inquiry has established that guidebooks have the potential to act as an influential form of 
interpretation by raising knowledge and understanding at the planning stage. This in turn has the potential to effect behaviour at the tourism destination. Guidebooks also have the potential to influence at the post-trekking stage where minimal impact knowledge and skills can be reinforced. This is particularly the case for users of guidebooks that Nishimura et al., (2007, p. 280) identified as guidebook enthusiasts, who use guidebooks to fulfill "learning” and “enjoyment” needs.

Much of what has been discussed so far concerns knowledge, which from a trekkers perspective can be dived into primary knowledge and secondary knowledge (see Figure 7). Primary knowledge is related to the safe undertaking of independent remote area travel. This knowledge includes how to construct/erect/use remote area shelters (e.g. tents, huts, bivouac bags, snow caves), finding safe drinking water, knowing what food to take and preparing food using camping stoves, route finding (reading a map, estimating distances and timing, using a compass or GPS), basic weather predication, and remote area first aid in case of accidents. Secondary knowledge relates to interpretative aspects and includes having an understanding of the natural environment, history, social and cultural background as well as reducing environmental impacts. In this inquiry the participant's knowledge and ability to recall secondary information such as reducing environmental impacts was poor; a possible reflection on the emphasis on primary knowledge.

\section{[Insert Figure 7]}

There is also the problem that experienced trekkers tend to become blasé to MIMs over time. A study on the effectiveness of MIMs on bulletin boards in National Parks in the United States found that trekkers and horse riders that had previous experience and exposure to 
messages were less attentive during future visits (McCool \& Cole, 2000). Manfredo and Bright (1991, p. 15) suggest that experienced trekkers are a harder group to influence because: (1) trekkers with more knowledge may perceive less utility in the information provided, (2) existing knowledge from previous treks may be seen as adequate, therefore there is no need for further information, (3) trekkers with previous experience may process the information quickly and not devote much time attending to messages, (4) more experienced trekkers are affected by the repetition of messages, and (5) experienced trekkers are more likely to question the credibility of the message source.

\section{Implications}

From the results of this study guidebooks have been shown to have the potential to raise environmental knowledge at all stages of a trek (planning, trekking, post-trek). If guidebooks are to become an effective form of interpretation and in the promotion of responsible environmental behaviour then MIMs need to be restructured and there delivery needs to appeal to the reader's characteristics. Marion and Reid's (2007) study on visitor education in protected areas found that message content, delivery, and audience characteristics need to be taken into account if MIMs are to be effective in changing environmental behaviour in visitors who lack the knowledge and skills to put these into practice.

It is recommended that the Elaboration Likelihood Model be used as a basis for constructing MIMs. Persuasiveness according to this model depends on a number of factors including the characteristics of the recipient(s) (e.g. level of intelligence, self-esteem, mood), the source of the message (e.g. claims to expertise, trustworthiness, attractiveness, the credibility of the message), the way in which the message is communicated (does it stimulate its intended audience), and the cognitive routes by which the message is evaluated by the recipient 
(Hovland, Janis \& Kelley, 1953; Petty \& Cacioppo, 1981; Petty \& Cacioppo, 1986; Petty, McMichael \& Brannon, 1992).

The Elaboration Likelihood Model is based on the assumption that people process messages deeply or superficially depending on the level of cognitive effort invested. This is based on the idea that most of us are cognitive misers who only expend psychic energy when it's required. Messages processed via the central route are closely scrutinized; persuasion and attitude change will depend upon the quality of the arguments and information presented. Messages processed via the peripheral route are not well attended to; persuasion and attitude change depends upon persuasion cues such as image, packaging and consistency.

In either case the message needs to appeal to the readers characteristics. Visitors to national parks, particularly those that venture unassisted into remote and/or wilderness areas are typically independent tourists, educated to degree level, have high levels of disposable income, are physically fit, predominately male (although the gap between gender is closing) and environmentally aware (Cole, Watson \& Roggenbuck, 1995). Even though this particular population may see themselves as environmental aware, they may not necessarily have the skills to put their environmental awareness into practice. In order for messages to be persuasive to this group they need to refer specifically to the activity they are undertaking so that the message has personal utility (McCool \& Cole, 2000). Secondly, it needs to come from a source with high level of credibility. A park service such as the TPWS would in most cases be considered to be a credible source for MIMs for this group - as opposed to guidebook authors. It is recommended then that park agencies such as the TPWS work with the publishers of guidebooks that cover their areas to incorporate a section or chapter devoted to visiting national parks. The emphasis here would be on providing information on the 
various parks and protected areas that come under the jurisdiction of the parks service and how visitors can best enjoy and reduce environmental impacts when onsite. Ideally this information would be well structured, providing consistent messages (consistent with those currently appearing on TPWS publications, poster and signs) as well as providing information on the appropriate behaviours to reduce impacts.

It is impossible to predict the cognitive effort that goes into reading a guidebook. Suffice to say there is scope in a guidebook to design MIMs that appeal to both deep (central route) and superficial (peripheral route) coverage of the material. MIMs can be structured to provide essential information, as well as supplementary detail for readers who wish to pursue the issues in more depth, and which would appeal to both experienced and inexperienced trekkers. The other option is for park services to take full control of the process by publishing their own guidebooks as the TPWS is currently doing. This enables protected area managers to influence both onsite and offsite interpretation. Given the creditability of most park services around the world it is suggested that park services make recommendations on their websites for existing guidebooks that carry MIMs consistent with their own. 


\section{References}

Ajzen, I. (2005). Attitudes, personality and behaviour ( ${ }^{\text {nd }}$ ed.). Maiden Head, UK: Open University Press.

Ajzen, I. \& Fishbein, M. (1980). Understanding attitudes and predicting social behavior. London: Prentice Hall.

Bain, C., Tsarouhas, G., \& Brown, B. (2005). Lonely Planet Guide to Tasmania. Footscray, Australia: Lonely Plane Publications.

Bain, A., Brown, L., Connellan, I., Daly, J.L., Dixon, G. \& van deer Knife, G. (2006). Lonely Planet Guide to Walking in Australia. Footscray, Australia: Lonely Planet Publications.

Ballantyne, R. \& Packer, J. (2005). Promoting environmentally sustainable attitudes and behaviour through free-choice learning experiences: What is the state of the game? Environmental Education Research. 11, 281-295.

Beck, W. (2006). Narratives of World Heritage in travel guidebooks. International Journal of Heritage Studies, 12, 521-535.

Beckmann, E.A. (2003). Listening between the lines. In R. Black \& B. Weiler (Eds.), Interpreting the land down under: Australian heritage interpretation and tour guiding (pp. 128-150). Golden, CO: Fulcrum Publishing.

Bhattacharyya, D.P. (1997). Mediating India: An analysis of a guidebook. Annals of Tourism Research, 24, 371-389.

Bright, A. (1994). Information campaigns that enlighten and influence the public. Parks \& Recreation, 29, 48-54.

Bryman, A. (2001). Social research methods ( $2^{\text {nd }}$ ed.). Oxford, UK: Oxford University Press.

Buckley, R. (2004). Impacts positive and negative: Links between ecotourim and environment. In R. Buckley (Ed.), Environmental impacts of ecotourism (pp. 5-14). Wallingford, UK: CABI.

Chapman, J. \& Chapman, M. (2006). Overland Track. Laburnum, Australia: John Chapman.

Chapman, J., Chapman, M. \& Siseman, J. (2006). Cradle Mountain Lake St Clair and Walls of Jerusalem National Parks (5 ${ }^{\text {th }}$ ed.). Laburnum, Australia: John Chapman.

Cole, D. N., Watson, A. E., \& Roggenbuck, J. W. (1995). Trends in wilderness visitors and visits: Boundary Waters Canoe Area, Shining Rock and Desolation Wilderness (INT$R P$-483). Ogden, UT: Intermountain Research Station, USDA Forest Service

Cottrell, S.P. and Graefe, A.R. (1997). Testing a conceptual framework of responsible environmental behaviour. Journal of Environmental Education, 29, 17-21. 
Eagles, P.F.J., McCool, S. \& Haynes , C.D. (2002). Sustainable tourism in protected areas: Guidelines for planning and management. Madrid: World Tourism Organisation.

Eagles, P. F. J., \& McCool, S. F. (2004). Tourism in national parks and protected areas: Planning and management. Wallingford, UK: CABI.

Fishbein, M. (1967). Attitude and the prediction of behaviour. In M. Fishbein (Ed.), Readings in attitude theory and measurement (pp. 477-492). New York: Wiley.

Fishbein, M. \& Azjen, I. (1975). Belief, attitude, intention and behavior: An introduction to theory and research. Reading, MA: Addison-Wesley.

Ham, S. \& Weiler, B. (2002). Interpretation as centrepiece of wildlife tourism. In R. Harris, T. Griffin \& P. Williams (Eds.), Sustainable tourism: A global perspective (pp. 3544). Oxford, UK: Elsevier.

Hill, J., Woodland, W., \& Gough, G. (2007). Can visitor satisfaction and knowledge about tropical rainforests be enhanced through biodiversity interpretation, and does this promote a positive attitude towards ecosystem conservation? Journal of Ecotourism, 6(1), 75-85.

Hines, J.M., Hungerford, H.R. \& Tomera, A.N. (1986/87). Analysis and synthesis of research on responsible environmental behavior: A meta-analysis. Journal of Environmental Education. 18, 1-8.

Hovland, C. I., Janis, I. L., \& Kelley, H. H. (1953). Communication and persuasion: Psychological studies of opinion change. New Haven, CT: Yale University Press.

Hughes, M., \& Saunders, A. M. (2005). Interpretation, activity participation, and environmental attitudes of visitors to Penguin Island, Western Australia. Society \& Natural Resources, 18, 611-624.

Hungerford, H.R. \& Volk, T.L. (1990). Changing learner behavior through environmental education. Journal of Environmental Education, 21, 8-21.

Iozzi, L.A. (1989). What research says to the educator: Part one: Environmental education and the affective domain. Journal of Environmental Education, 20, 3-9.

Jacobsen, J.K.S., Heimtun, B. and Nordbakke, S.T.D. (1998) Det Nordlige Norges Image: Innholdsanalyse av Utenlandske Reisehåndbøker (The Image of Northern Norway: Content Analysis of Foreign Guidebooks). Research Report 398. Oslo, Norway: Institute of Transport Economics, Norwegian Centre for Transport Research.

Kelly, M. (1998). Tourism, not terrorism: The visual politics of presenting Jordan as an international tourist destination. Visual Anthropology, 11, 191-205.

Kuo, I.-L. (2002). The effectiveness of environmental interpretation at resource-sensitive tourism destinations. International Journal of Tourism Research, 4, 87-101. 
Lew, A. A. (1991). Place representation in tourist guidebooks: An example from Singapore. Singapore Journal of Tropical Geography, 12, 124-137.

Littlefair, C. J. (2004). Reducing impacts through interpretation, Lamington National Park. In R. Buckley (Ed.), Environmental impacts of ecotourism (pp. 297-307). Wallingford, UK: CABI.

Lonely Planet. (2008). Thorn tree. Retrieved 1 July, 2008, from www.lonelyplanet.com/thorntree

Manfredo, M. \& Bright, A. (1991). A model for assessing the effects of communication on recreationists. Journal of Leisure Research, 23, 1-20.

Marion, J.L. \& Reid, S.E. (2007). Minimising visitor impacts to protected areas: The efficacy of low impact education programmes. Journal of Sustainable Tourism, 15, 5-27.

McCool, S. \& Cole, D. (2000). Communicating minimal impact behaviour with trailside bulletin boards: Visitor characteristics associated with effectiveness. USDA Forest Service Proceedings, 4, 208-216.

McGregor, A. (2000). Dynamic texts and tourist gaze: Death, bones and buffalo. Annals of Tourism Research, 27, 27-50.

Minichiello, V., Aroni, R., Timewell, E., \& Alexander, L. (1995). In-depth interviewing: Principles, techniques, analysis (2nd ed.). Melbourne, Australia: Pearson.

Munro, J. K., Morrison-Saundersa, A., \& Hughesb, M. (2008). Environmental interpretation evaluation in natural areas. Journal of Ecotourism, 7, 1-14.

Nishimura, S., Waryszak, R., \& King, B. (2006). Guidebook use by Japanese Tourists: A qualitative study of Australia inbound travellers. International Journal of Tourism Research, 8, 13-26.

Nishimura, S., Waryszak, R., \& King, B. (2007). The use of guidebooks by Japanese overseas tourists: A quantitative approach. Journal of Travel Research, 45, 275-284.

Orams, M.B. (1997). The effectiveness of environmental interpretation: Can we turn tourists into 'greenies'. Progress in Tourism and Hospitality Research, 3, 295-306.

Petty, R. E., \& Cacioppo, J. T. (1981). Attitudes and persuasion: Classic and contemporary approaches. Dubuque, IA: Wm. C. Brown.

Petty, R. E., \& Cacioppo, J. T. (1986). Communication and persuasion: Central and peripheral routes to attitude change. New York: Springer.

Petty, R.E., McMichael, S. \& Brannon, L.A. (1992). The elaboration likelihood model of persuasion: Applications in recreation and tourism. In M. Manfredo (Ed.), Influencing human behavior: Theory and applications in recreation, tourism, and natural resources management (pp. 77-101). Champaign, IL: Sagamore Publishing. 
Philips, A. (1989). Interpreting the countryside and natural environment. In D. Uzzell (Ed.), Heritage interpretation: The natural and built environment. London: Belhaven.

Roggenbuck, J. (1992). Use of persuasion to reduce resource impacts and visitor conflicts. In M. Manfredo (Ed.), Influencing human behaviour: Theory and applications in recreation, tourism and natural resources management (pp. 149-208). Champaign, IL: Sagamore Publishing.

Scott, P. D. (1998). Guidebooks: Prewar to postwar imaging. Journal of Intercultural Studies, 25, 89-106.

Siegenthaler, P. (2002). Hiroshima and Nagasaki in Japanese guidebooks. Annals of Tourism Research, 29, 1111-1137.

Stewart, W., Cole, D., Manning, R., Valliere, W., Taylor, J. \& Lee, M. (2000). Preparing for a day hike at Grand Canyon: What information is useful? USDA Forest Service Proceedings, 4, 221-225.

Tasmania Parks and Wildlife Service (TPWS). (2006). The Overland Track: One walk, many journeys. Hobart, Tasmania: Parks and Wildlife Service Tasmania.

Therkelsen, A. \& Sorensen, A. (2005). Reading the tourist guidebook: Tourists' ways of reading and relating to guidebooks. Journal of Tourism Studies, 16, 48-60.

Tourism Queensland. (2007). Visitation to national parks. Retrieved 24 July, 2007, www.tq.com.au/fms/tq_corporate/research/fact_sheets/visitation_to_national_parks.p df.

Tubb, K.N. (2003). An evaluation of the effectiveness of interpretation within Dartmoor National Park in reaching the goals of sustainable tourism development. Journal of Sustainable Tourism, 11, 476-498.

Vaisutis, J., Murphy, A., Dunford, G., Carter, T., Dunston, L., Gaskell, K., et al. (2007). Lonely Planet Guide to Australia. Footscray, Australia: Lonely Planet Publications.

Vaughan, J. (1974). The English guide book, c 1780-1870. An illustrated history. London: David \& Charles.

Wearing, S., Archer, D. \& Beeton, S. (2007). Sustainable marketing of tourism in protected Areas: Moving forward - Summary Sheet. Griffith University, Gold Coast, Australia: Sustainable Tourism Cooperative Research Centre.

Wearing, S., Cynn, S., Ponting, J., \& McDonald, M. (2002). Converting environmental concern into ecotourism purchases: A qualitative evaluation of international backpackers in Australia. Journal of Ecotourism, 1(2-3), 133-148.

Weaver, D. (2006). Sustainable tourism. Oxford, UK: Elsevier. 
Figure 1: Growth in the number of protected areas around the world - 1900 to Present

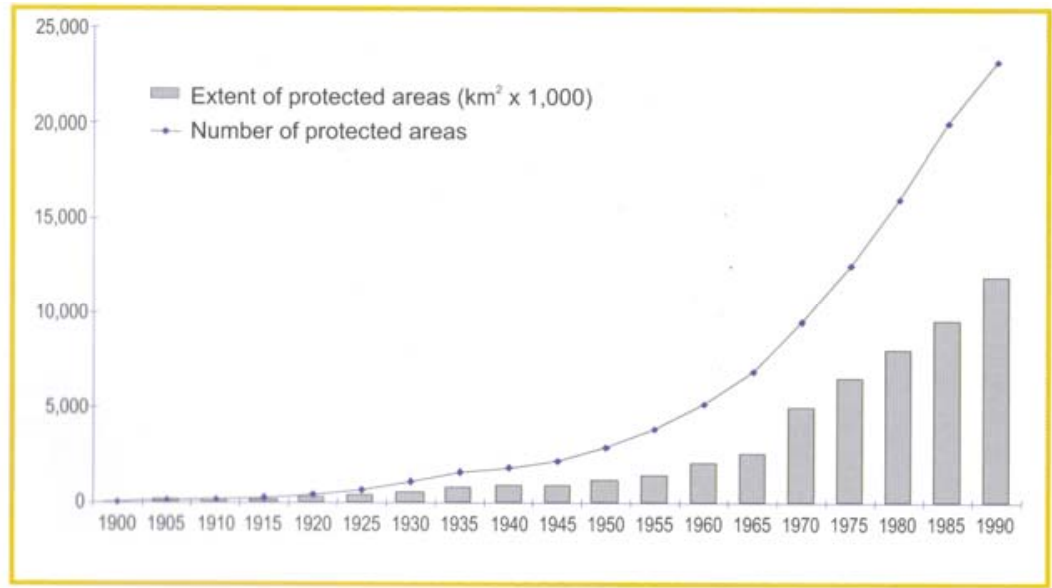

Source: Eagles et al. (2002).

Figure 2: Linear Behavioural Change System

\begin{tabular}{|l|l} 
Knowledge & $\begin{array}{c}\text { Awareness or } \\
\text { Attitudes }\end{array}$
\end{tabular} Action

Source: Hungerford and Volk (1990). 
Figure 3: Tasmania’s National Parks Including Cradle Mt - Lake St Clair National Park

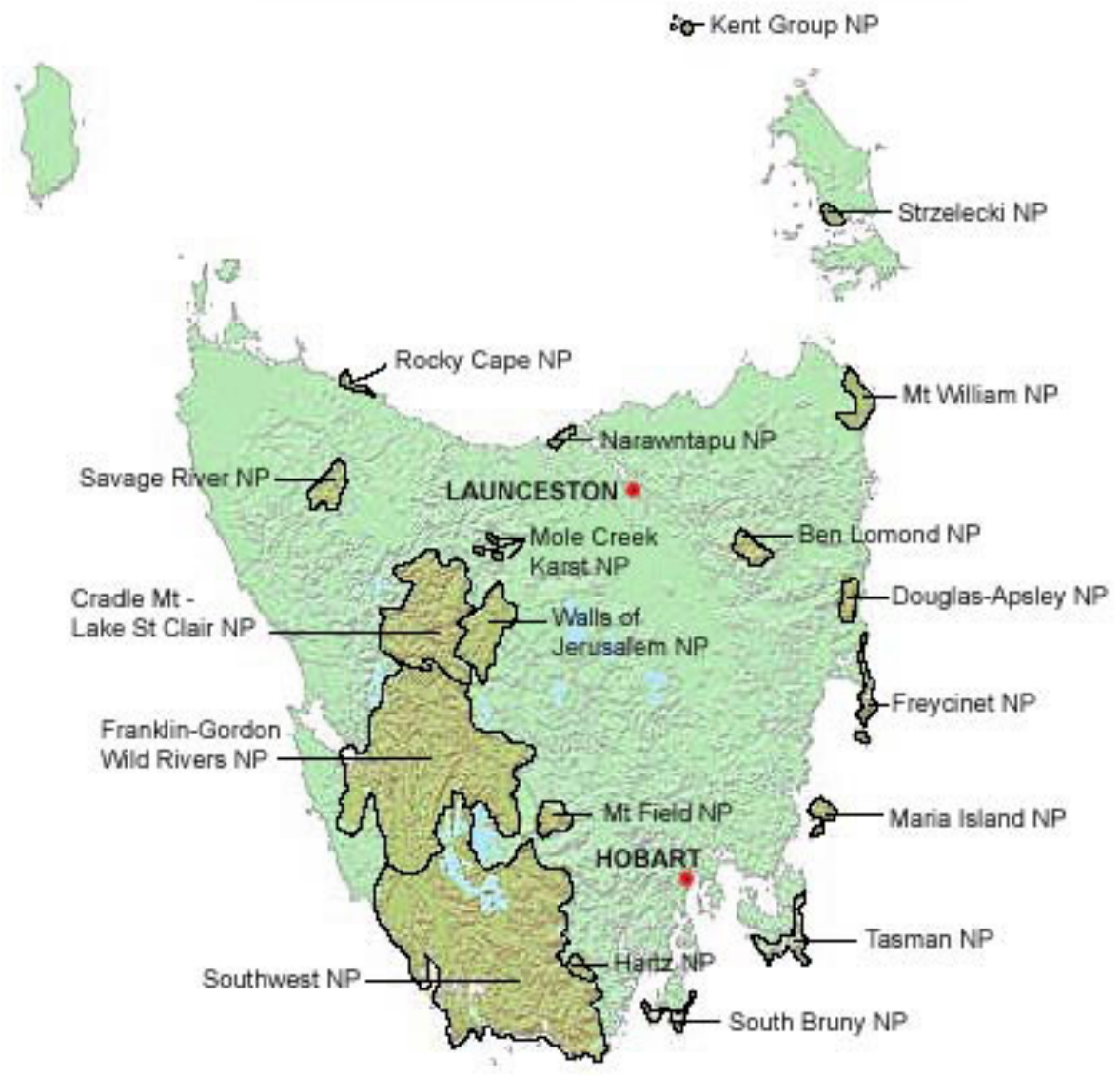

Source: Parks and Wildlife Service Tasmania (2007) 
Figure 4: Trekking Information Mix

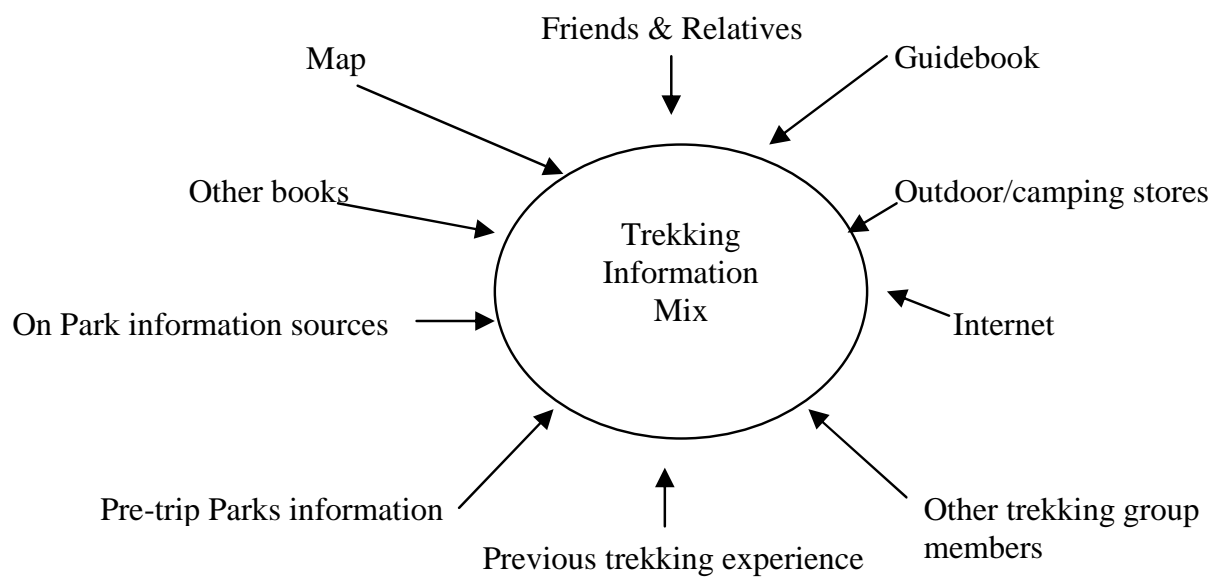

Figure 5: Hierarchical Message Structure for Interpretive Text

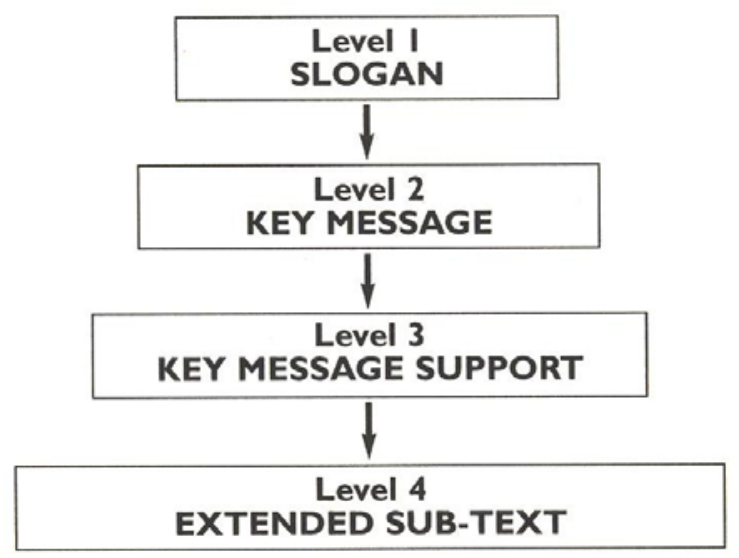

Source: Beckmann (2003, p. 139). 
Figure 6: Information Influence Spectrum

\begin{tabular}{|c|} 
Planning \\
(offsite)
\end{tabular}

- Guidebook

- Internet

- $\quad$ Friends \& relatives

- Map

- Outdoor/ camping stores

- $\quad$ Other trek group members

- $\quad$ Previous trekking experience

- $\quad$ Pre-trip parks service information

- $\quad$ Other books
- Guidebook

- Map

- $\quad$ Other trek group members

- $\quad$ Previous trekking experience

- $\quad$ On track information sources

- $\quad$ Other books
- Guidebook

- Internet

- $\quad$ Previous trekking experience

- Other books

Figure 7: Knowledge Areas for Trekking

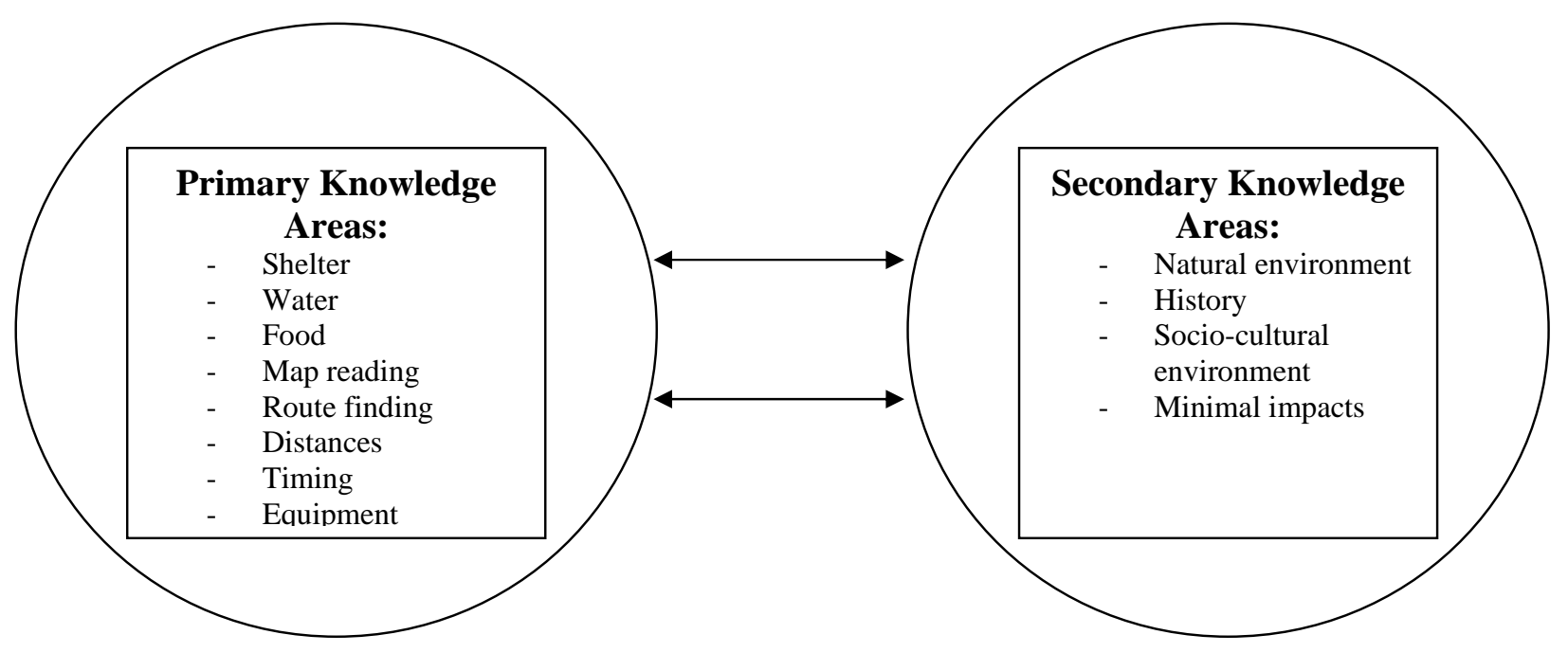


Table 1: Levels of Undesirable Behaviour

\begin{tabular}{|c|c|c|}
\hline $\begin{array}{c}\text { Undesirable } \\
\text { Behaviour }\end{array}$ & Description & Example \\
\hline Careless & Thoughtless behaviour. & Littering. \\
\hline Unskilled & $\begin{array}{l}\text { When visitors know what they should } \\
\text { be doing, but lack the necessary } \\
\text { skills. }\end{array}$ & $\begin{array}{l}\text { Not building a low impact } \\
\text { campfire. }\end{array}$ \\
\hline Uninformed & $\begin{array}{l}\text { Visitors not having adequate } \\
\text { information on certain behaviours. }\end{array}$ & $\begin{array}{l}\text { Feeding wildlife without } \\
\text { knowing that the } \\
\text { behaviour violates } \\
\text { regulations or } \\
\text { recommendations. }\end{array}$ \\
\hline Unavoidable & $\begin{array}{l}\text { Behaviour that occurs despite visitor } \\
\text { knowledge or experience. }\end{array}$ & Vegetation trampling. \\
\hline Illegal & Deliberate violations of the laws. & $\begin{array}{l}\text { Vandalising Aboriginal } \\
\text { artwork. }\end{array}$ \\
\hline
\end{tabular}

Source: Roggenbuck (1992). 
Table 2: Comparison of Theories of Behaviour Change

\begin{tabular}{|c|c|c|}
\hline Theory or Model & References & Key Concepts \\
\hline $\begin{array}{l}\text { Theory of Planned } \\
\text { Behaviour \& } \\
\text { Theory of } \\
\text { Reasoned Action }\end{array}$ & $\begin{array}{l}\text { (Ajzen, 2005; } \\
\text { Ajzen \& Fishbein, } \\
\text { 1980; Fisbein, } \\
\text { 1967; Fishbein \& } \\
\text { Ajzen, 1975). }\end{array}$ & $\begin{array}{l}\text { Human behaviour, or at least behavioural } \\
\text { intention, is consistent with attitudes, and } \\
\text { these attitudes are consistent with beliefs. } \\
\text { Behavioural intention is affected by } \\
\text { attitude towards behaviour (behavioural } \\
\text { beliefs and evaluation of those beliefs), } \\
\text { subjective norm (normative beliefs and } \\
\text { motivation to comply with those beliefs), } \\
\text { and perceived behavioural control } \\
\text { (control beliefs). }\end{array}$ \\
\hline $\begin{array}{l}\text { Elaboration } \\
\text { Likelihood Model }\end{array}$ & $\begin{array}{l}\text { (Hovland, Janis \& } \\
\text { Kelley, 1953; Petty } \\
\text { \& Cacioppo, 1981; } \\
\text { Petty \& Cacioppo, } \\
\text { 1986; Petty, } \\
\text { McMichael \& } \\
\text { Brannon, 1992). }\end{array}$ & $\begin{array}{l}\text { Motivation and ability to process } \\
\text { arguments determines whether } \\
\text { persuasion is via central or peripheral } \\
\text { route. The central route involves high } \\
\text { elaboration of message, whereas the } \\
\text { peripheral route influences through cues } \\
\text { tangential to the message. }\end{array}$ \\
\hline $\begin{array}{l}\text { Model of } \\
\text { Responsible } \\
\text { Environmental } \\
\text { Behaviour }\end{array}$ & $\begin{array}{l}\text { (Hines et al., } \\
\text { 1986/87). }\end{array}$ & $\begin{array}{l}\text { Intention to act in an environmentally } \\
\text { responsible manner is influenced by } \\
\text { action skills, knowledge of action } \\
\text { strategies, knowledge of issues and } \\
\text { personality factors (including attitudes, } \\
\text { locus of control and personal } \\
\text { responsibility). }\end{array}$ \\
\hline
\end{tabular}

Source: Littlefair (2004). 
Table 3: Features of Guidebooks

\begin{tabular}{|l|l|l|}
\hline Guidebook & Feature 1 & Feature 2 \\
\hline $\begin{array}{l}\text { The Overland Track: One walk } \\
\text { many journeys (TPWS, 2006) }\end{array}$ & Trekking route & Natural environment \\
\hline $\begin{array}{l}\text { The Overland Track (Chapman \& } \\
\text { Chapman, 2006) }\end{array}$ & Trekking route & \\
\hline $\begin{array}{l}\text { Lonely Planet Guide to Tasmania } \\
\text { (Bain, Tsarouhas \& Brown, 2005) }\end{array}$ & Transport & Accommodation \\
\hline $\begin{array}{l}\text { Lonely Planet Guide to Walking in } \\
\text { Australia (Bain et al., 2006) }\end{array}$ & Trekking route & Transport \\
\hline $\begin{array}{l}\text { Lonely Planet Guide to Australia } \\
\text { (Vaisutis, Murphy, Dunford, } \\
\text { Carter, Dunston, Gaskell et al., } \\
\text { 2007) }\end{array}$ & Transport & Accommodation \\
\hline $\begin{array}{l}\text { Cradle Mountain Lake-St Clair and } \\
\text { Walls of Jerusalem National Parks } \\
\text { (Chapman, Chapman \& Siseman, } \\
\text { 2006) }\end{array}$ & Trekking route & \\
\hline
\end{tabular}


Table 4: Guidebooks - Comparison of Minimal Impact Messages

\begin{tabular}{|c|c|c|c|c|c|}
\hline $\begin{array}{l}\text { Key } \\
\text { Impact } \\
\text { Messages }\end{array}$ & $\begin{array}{l}\text { The Overland } \\
\text { Track: One } \\
\text { walk many } \\
\text { journeys } \\
\text { (TPWS, 2006) }\end{array}$ & $\begin{array}{c}\text { Cradle } \\
\text { Mountain } \\
\text { Lake-St Clair } \\
\text { and Walls of } \\
\text { Jerusalem } \\
\text { National } \\
\text { Parks } \\
\text { (Chapman, } \\
\text { Chapman \& } \\
\text { Siseman, } \\
\text { 2006) }\end{array}$ & $\begin{array}{l}\text { The } \\
\text { Overland } \\
\text { Track } \\
\text { (Chapman } \\
\text { \& } \\
\text { Chapman, } \\
\text { 2006) }\end{array}$ & $\begin{array}{l}\text { Lonely Planet } \\
\text { Guide to } \\
\text { Tasmania } \\
\text { (Bain, } \\
\text { Tsarouhas \& } \\
\text { Brown, 2005) }\end{array}$ & $\begin{array}{c}\text { Lonely } \\
\text { Planet } \\
\text { Guide to } \\
\text { Walking } \\
\text { in } \\
\text { Australia } \\
\text { (Bain et } \\
\text { al., 2006) }\end{array}$ \\
\hline Fires & & & & & \\
\hline Track & & & & & \\
\hline Rubbish & & & & & \\
\hline $\begin{array}{l}\text { Camping } \\
\text { location }\end{array}$ & & & & & \\
\hline $\begin{array}{l}\text { Animal } \\
\text { feeding }\end{array}$ & & & & & \\
\hline $\begin{array}{l}\text { Water/deter } \\
\text { gents/soaps }\end{array}$ & & & & & \\
\hline Hut usage & & & & & \\
\hline Stoves & & & & & \\
\hline Toilets & & & & & \\
\hline Group size & & & & & \\
\hline $\begin{array}{l}\text { Plant } \\
\text { disease }\end{array}$ & & & & & \\
\hline Fan out & & & & & \\
\hline $\begin{array}{l}\text { Walking } \\
\text { poles }\end{array}$ & & & & & \\
\hline
\end{tabular}


Table 5: Message Structure Explanation

\begin{tabular}{|l|l|}
\hline \multicolumn{1}{|c|}{ Level Number \& Name } & \multicolumn{1}{c|}{ Definition } \\
\hline 1. Slogan & $\begin{array}{l}\text { Single phrase intended to communicate the general MIM } \\
\text { through a simple directive (telling people what to do). }\end{array}$ \\
\hline 2. Key message & $\begin{array}{l}\text { Short, memorable phrases that summarise the simple } \\
\text { behavioural directive. }\end{array}$ \\
\hline 3. Key message support & $\begin{array}{l}\text { Additional phrases to extend and interpret each key } \\
\text { message. }\end{array}$ \\
\hline 4. Extended sub-text & $\begin{array}{l}\text { More extensive, concise text, to describe more specific } \\
\text { minimal impact behaviours and their rationale within the } \\
\text { context of fragile environments. }\end{array}$ \\
\hline
\end{tabular}

Source: Beckmann (2003, p. 139). 